\title{
Space-Time Analysis of Quarrels in Ardabil City, Iran
}

\section{A R T I C L E I N F O}

\section{Article Type}

Original Research

\section{Authors}

Pashazadeh A. ${ }^{1} M A$,

Yazdani $\mathrm{M}^{* 1} \mathrm{PhD}$,

Mohammadi A. ${ }^{1} \mathrm{PhD}$

\section{How to cite this article}

Pashazadeh A, Yazdani M, Moham-

madi A. Space-Time Analysis of Qu-

arrels in Ardabil City, Iran. Geogra-

phical Researches Quarterly Journ-

al. 2019;34(2):293-302.
${ }^{1}$ Department of Urban \& Rural Planning, Faculty of Literature \& Humanities, Mohaghegh Ardabili University, Ardabil, Iran

\section{*Correspondence}

Address: Department of Urban \& Rural Planning, Faculty of Literature \& Humanities, University Street, Mohaghegh Ardabili University, Ardabil, Iran. Postal Code: 56199-13131 Phone: +98 (45) 33516401

Fax: +98(45) 33516402 yazdani.m51@gmail.com

\section{Article History}

Received: May 23, 2018

Accepted: March 7, 2019

ePublished: June 20, 2019

\section{A B S T R A C T}

Aims \& Backgrounds Involvement is one of the most experienced human crimes, which endangers the financial, and life security of individuals and society and its study is most important to increase the security of individuals and society. Investigation of quarrel occurrence shows that this crime occurs at specific times and places. Therefore, the main aim of this study was to the identification of the most common times and places of quarrel occurrence in Ardabil city.

Methodology The descriptive-analytical study was carried out on imprisoned criminals because of the quarrel/conflict in the first half of 2017 who served their sentences in Ardabil city. The subjects ( $N=111)$ completed the questionnaire. Data analysis were conducted using Chi-square and Cramer tests through SPSS 19 software, and using spatial statistics (Average nearest neighbor, standard deviation distribution curve model, central limit theorem and Kernel density estimation model) through ArcGIS software.

Findings Most of the quarrels were conducted during the spring season, especially in May and Jun, early, and late of each week and midday of each day. More involvements occur in the peripheral and worn out tissues of the city, where the population density is high, and according to the output of the kernel density map, the dispersion of the conflicts follow a cluster pattern. According to the output of the kernel density map, dispersion of conflicts and quarrels followed the cluster pattern. There was a significant relationship between the place of residence and the location of the quarrel. The most frequent location of the quarrel was the central and northwestern parts of the Ardabil city.

Conclusion Time and place are the effective factors in the occurrence of quarrel and they have different effects considering the spatiotemporal conditions.

Keywords Crime Time; Crime Place; Quarrel; Ardabil City

\section{I T A T I O N L I N K S}

[Abdi, et al; 2008] Effective factors on force robbery occurrence at Karaj city; [Afzali \& Ghaleiha; 2006] Battery epidemiologic investigation and its damages for 1381 solar year referral persons for Hamedan law medical center; [Ahmadi, et al; 2013] Guilty patterns spatial analysis at Tehran 17th municipality region; [Barani-Birarvand, et al; 2010] Guilty time-space patterns analysis at urban regions (case study: Robbery, force, depravity and levy at Tehran city central part); [Felson \& Clarke; 1998] Opportunity makes the thief practical theory for crime prevention; [Foroozandeh, et al; 2013] Investigation effective factors on battery toward among Ardebil citizens; [Ghaffari, et al; 2017] Measurement and priority of city resistance against earthquake (case study: Ardebil city and its quad part regions); [Hossienzadeh, et al; 2011] Sociological investigation of effective factors on social battle toward, case study: Ahvaz city; [Kalantari, et al; 2010] Investigation of field application amount and effect in crimes centers creation by using GIS (Geographical Information Systems) bases; [Kalantari \& Tavakkoli;2007] Urban crime centers analysis and recognition; [Keynia; 1994] Criminology principals; [Modiri; 2007] Crime, violence and security feeling in city public spaces; [Nouri; Mohammad Hossieni; 2014] Ardebil province crime regions recognition; [Pashazadeh, et al; 2017] Recognition of crimes occurrence place and time at Ardebil city focused on delinquency and guilt theory; [Pour Afkari; 2011] Analysis of race tensions in Iran, selective articles of the first national congress about tribes and races role in prevention of social battles, Gachsaran; [Shams, et al; 2012] Analysis relationship between crime and population congestion in statistical blocks by using GIS (Geographical Information Systems) bases (case study: ZanjanIslamabad informal residence place); [Varvaei, et al; 2011] Investigation effective factors of robberies close to suffering at Bandar-Abbas city (2010) by crime position prevention survey 
نوعدوستى بودهاند. آنجه كه مسالهآفرين است وجود تضادها و رويارويىهاى خشونتآميز در بين افراد و گروهها است. يكى از از

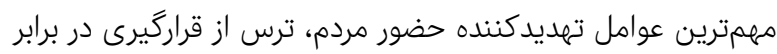

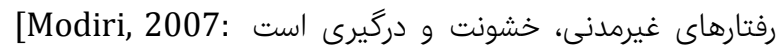

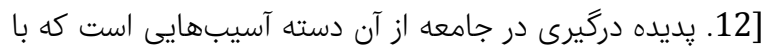

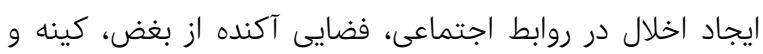

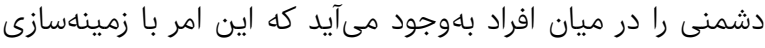

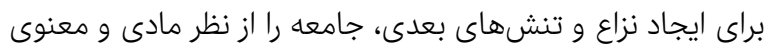

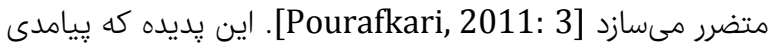
جز ضربوجرح ندارد، يك آسيب اجتماعى است كه مانند ساير

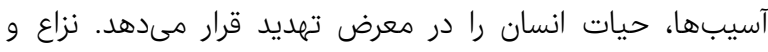

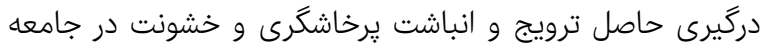
است و اين واقعيت غيرقابلانكار در ساحتهاى مختلف اجتماع ورداع

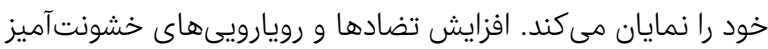
در بين افراد جامعه، علاوه بر برهم خوردن نظم اجتماعى و فرسايش إنى

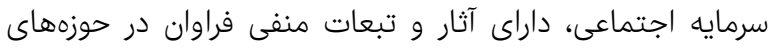

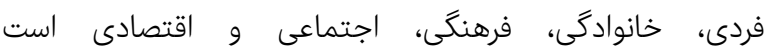

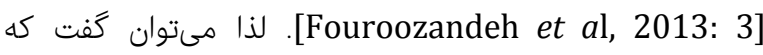

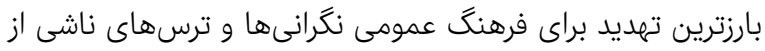

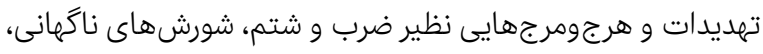

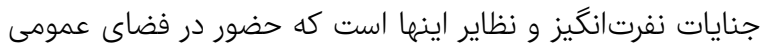

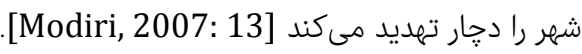
جامعهشناسان و آسيبشناسان اجتماعى يكى از از عمدهترين

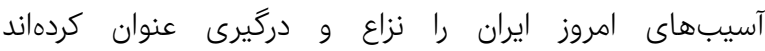

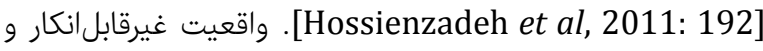
توأم با نكرانى جدى امروز ما، گسترش خشونت و درگيرىهاى

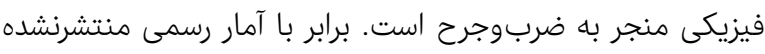

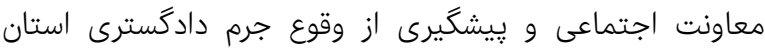

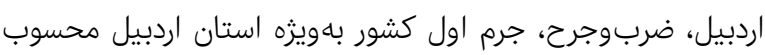

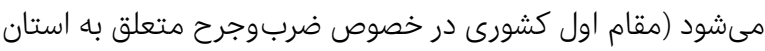

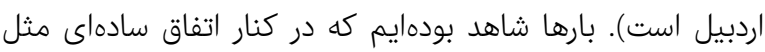

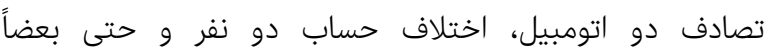
اختلافنظر، دركيرى و نزاع هم است. آستانه تحمل مردم كمتر شده

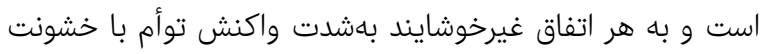

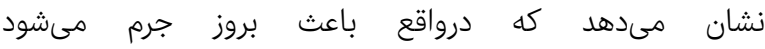
.[Fouroozandeh et al, 2013: 10] جرم از جمله مفاهيمى است كه بهشدت تحت تأثير مشخصههايى

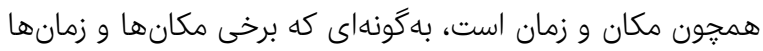

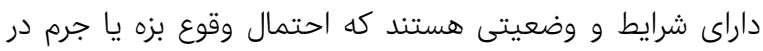

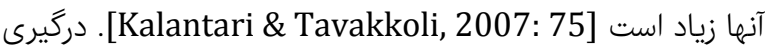

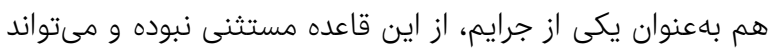

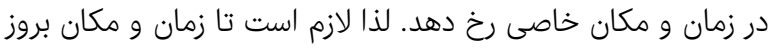

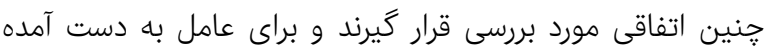
برنامههايى ارايه گردد.
تحليل زمانى-فضايى وقوع نزاع/دركيرىها در شهر

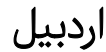

MA اصغر ياشازاده

كروه برنامهريزى شهرى و و روستايى، دانشكده ادبيات و علوم انسانى، دانشكاه محقق اردبيلى، اردبيل، ايران

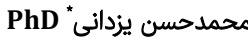

كروه برنامهريزى شهرى و وردئ روستايى، دانشكده ادبيات و علوم انسانى، دانشكاه محقق اردبيلى، اردبيل، ايران

Pليرضا محمدى PhD كروه برنامهريزى شهرى و وردي روستايى، دانشكده ادبيات و علوم انسانى، دانشكاه محقق اردبيلى، اردبيل، ايران

جكيده اهداف و زمينهها: نزاع/دركيرى يكى از باسابقهترين جرايم بشرى است كه امنيت

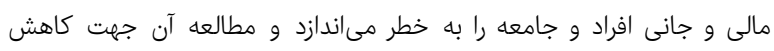

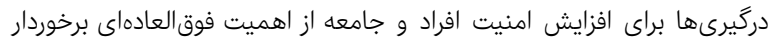

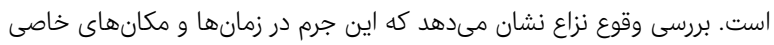

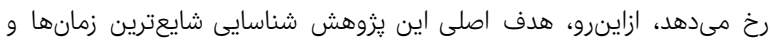

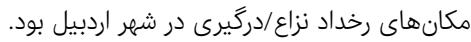

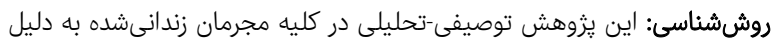

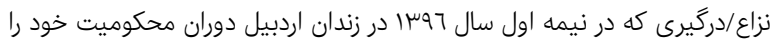

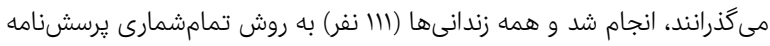

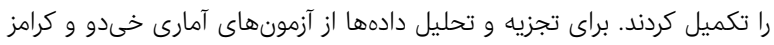

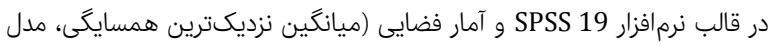

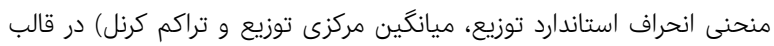

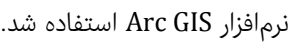

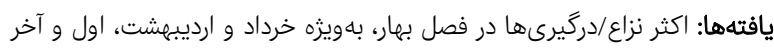

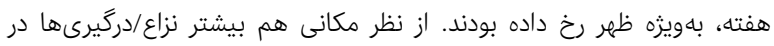

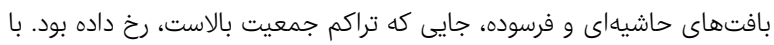

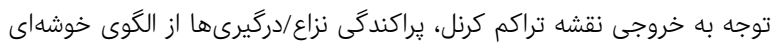

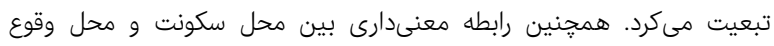

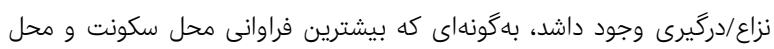

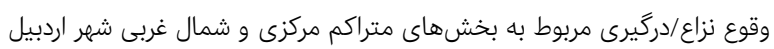

نتيجه گيرى: زمان و مكان از عوامل تأثيرگذار در بروز نزاع/درگيرى هستند، اما با

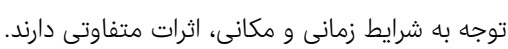

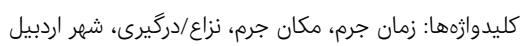

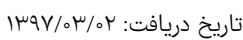
تاريخ קذيرش: تاريخ درياف: "نويسنده مسئول: yazdani.m51@gmail.com

مقدمه

انسانها در طول تاريخ حيات اجتماعى خويش بر اساس زمينههاى

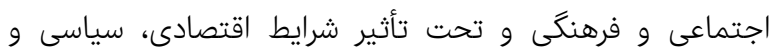

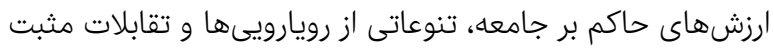

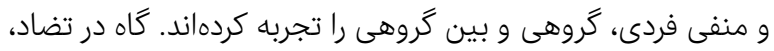

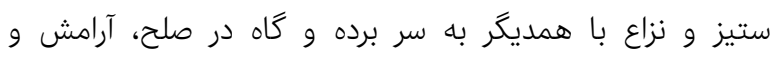


شنبه، يكشنبه و جهارشنبه و غالباً روز و وقت ادارى رخ رخ مىدهئ

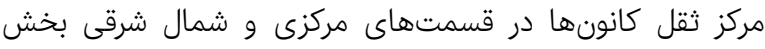

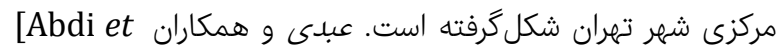
al, 2008] تحليل فضايى جرم در كرج را كاركردهاند و نتايج تحقيق

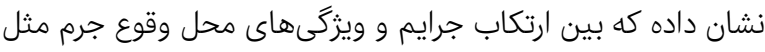

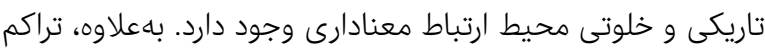

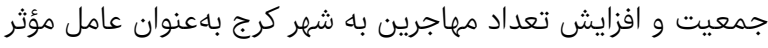

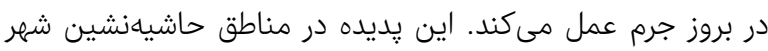
كرج سبب افزايش ميزان جرايم شده است. بإشازاده و همكاران

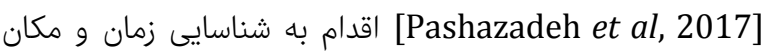
بروز جرايم در شهر اردبيل يرداختهاند. يافتههاى تحقيق آنها نشان إنان

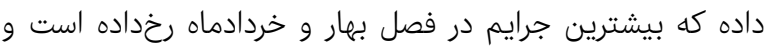
اينكه بيش از نيمى از جرايم در آخر هفته اتفاق إنتان إنتاده است.

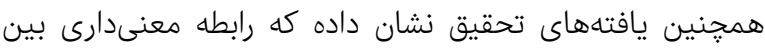

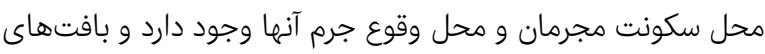
فرسوده با توجه به كيفيت محيطى كه دارند مستعد بروز جرم اند هستند.

با بررسى تحقيقات ذكرشده مىتوان كَتت كه در زمينه زمان و مكان

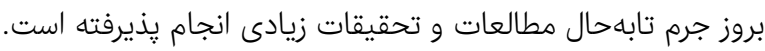

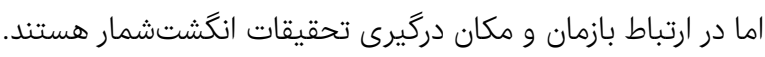
در خصوص جرم دركيرى در شهر اردبيل هم تنها يك موردتحقيق

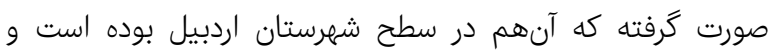

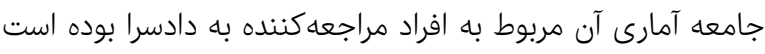

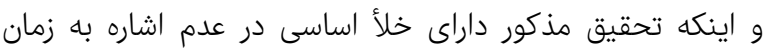

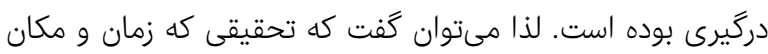

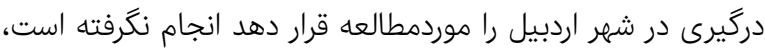

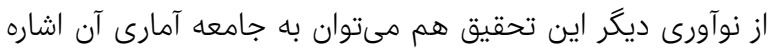

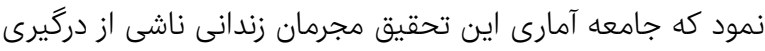

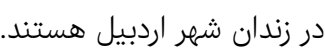
نزاع و دركيرى، كنشى است بهرقصد آسيبرساندن به فردئ فرد ديكرى

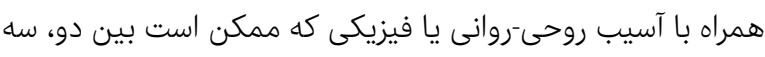

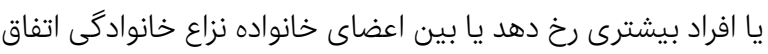

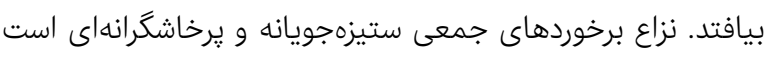

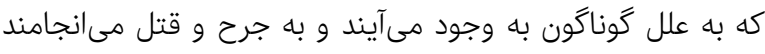
[Pourafkari, 2011: 375]

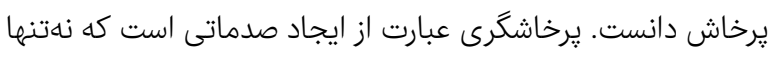

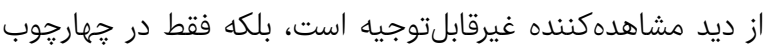

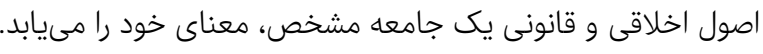

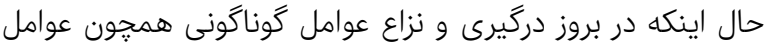

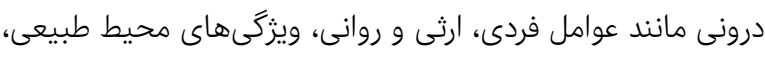

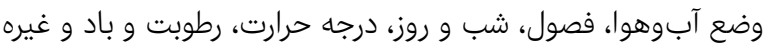

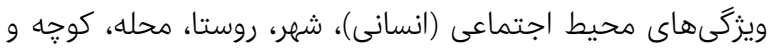

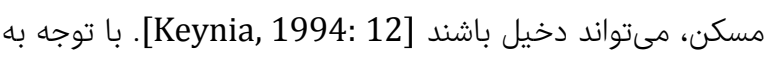
اينكه تأكيد اين تحقيق عامل زمان و مكان استان، لذا در ادامه
در خصوص زمان و مكان وقوع جرم، تحقيقات نسبتاً زيادى

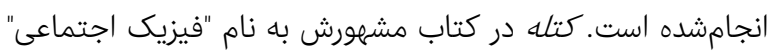

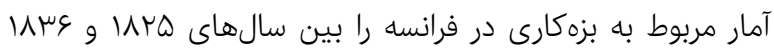

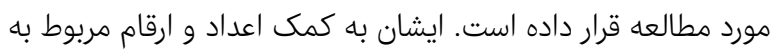

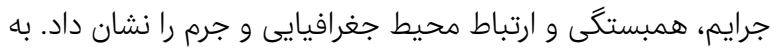

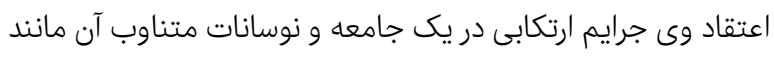
يك تابع رياضى وابسته به تغييرات شرايط اقتصادى و و اجتماعى دانى

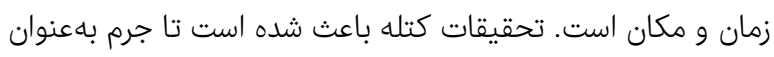

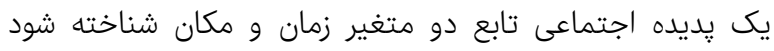

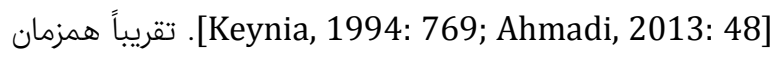

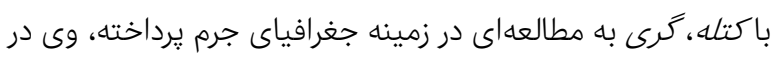

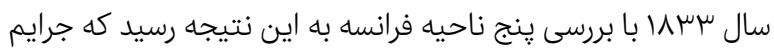

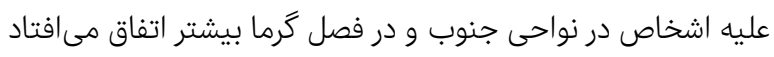

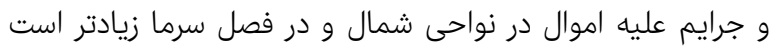

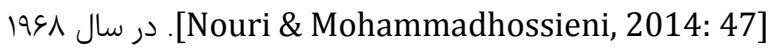
آنكلز در بررسى جرايم خيابانى كاليفرنيا، ارتباط بين جرم و تراكم

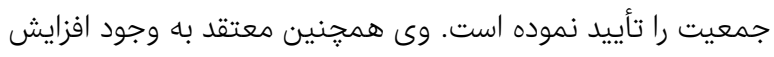

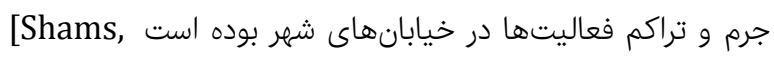

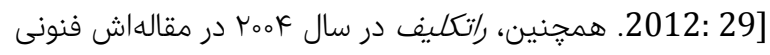
را براى شناخت تركيب فضايى و زمانى كانونهاى جرم خيز ارائ درايه

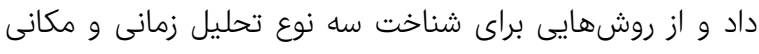

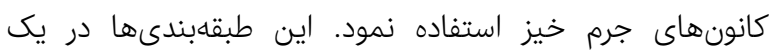

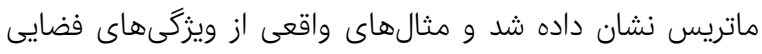

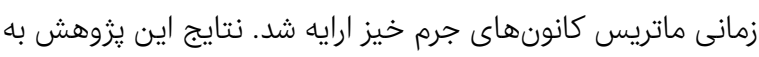

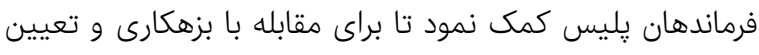

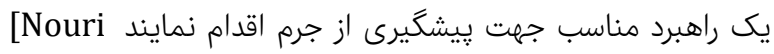

\& Mohammadhossieni, 2014: 52]

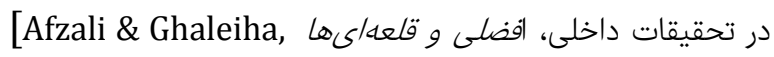

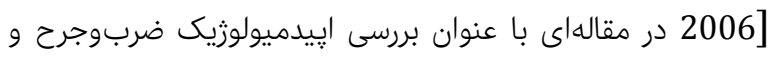

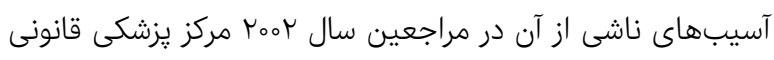

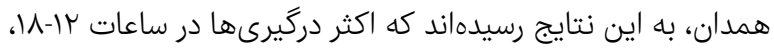

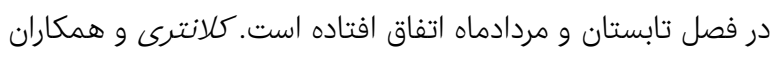

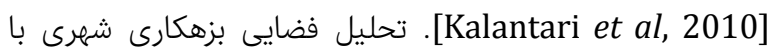

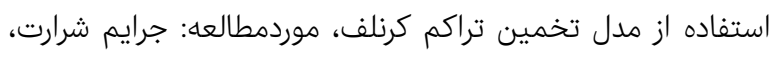

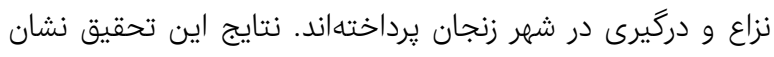

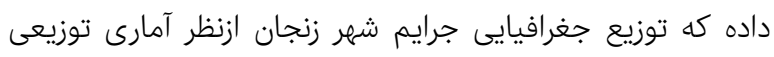

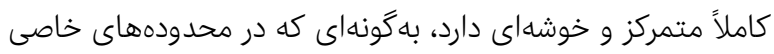

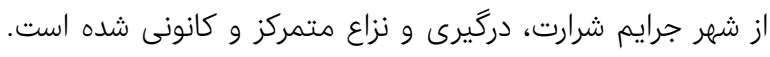

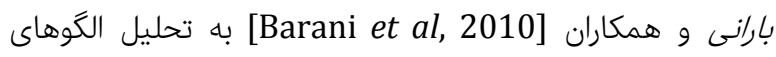
مكانى-زمانى بزهكارى در مناطق شهرى (مطالعه موردى: جرايم

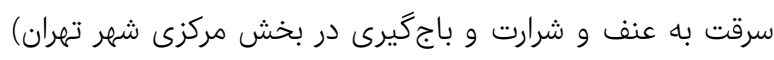

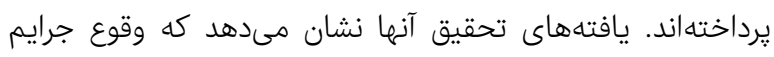

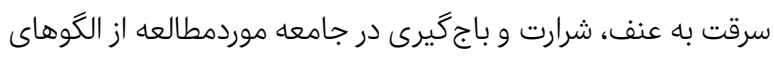
مكانى و زمانى خاص يِيروى مى كنند و بيشتر جرايم در در روزهاى 
جدول () نظريههاى مطرح در خصوص زمان و مكان وقوع جرم

توضيح نظريه

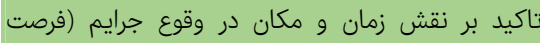

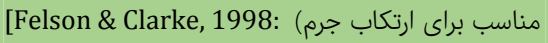

\section{.4]}

در واقع ارتكاب جرم نيازمند تقارن زمانى و مكانى بزهكار بالقوه و آماج بالقوه است. مكان، زمان و انسان (مجرم) عناصر مهم ارتكاب جرم

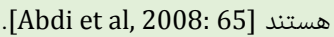

(اقتريه انتخاب عقلانى (اقتصاددانان در رشته

جرمشناسى، دهه

(191.

كانون جرمخيز، مكان يا محدوده جغرافيايى است كه

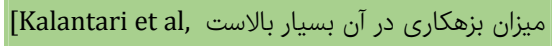

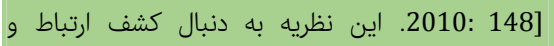
تغييرات در بين جرم و زمان وقوع آن است (ميزان جرايم

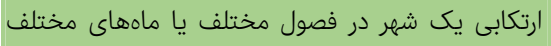
سال، روزهاى هفته و ساعات مختلف شبانهروز).

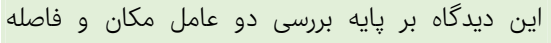

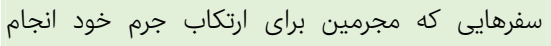
مىدهند استوار است. سفرهاى مجرمانه، با فاصله گرفتن از محل سكونت مجرمان كاهش مئيابد Pashazadeh] .et al, 2014: 149]

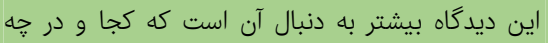

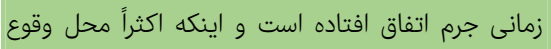

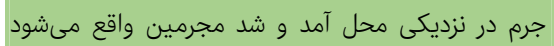
.[Salami et al, 2012: 93] اين ديدكاه به بررسى تأثير زيستگًاه فردى و محل زيست

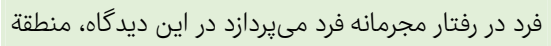

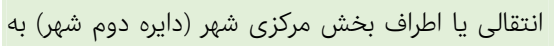

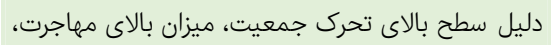

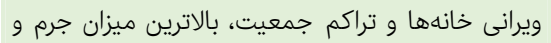

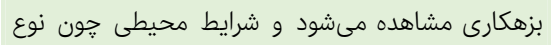

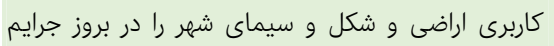

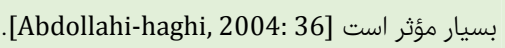
ميزان جرم رابطه ى مستقيمى با احساس نامنى استى دارد و

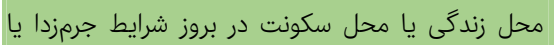

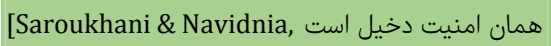
2006: 90] محل سكونت در نحوه ارتكاب جرم و نوع آن تأثير بسيار

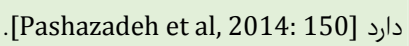
تراكم جمعيت، باعث احساس تنهايى و گمنامى افراد

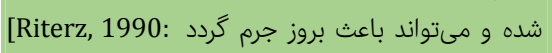

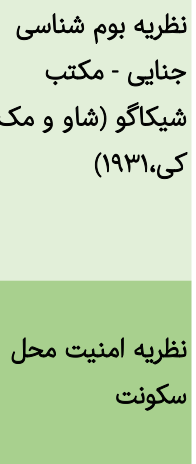

نظريه انريكو فرى

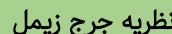

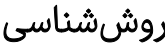

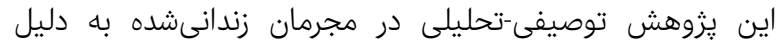

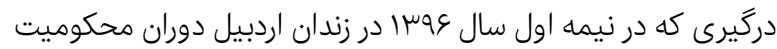

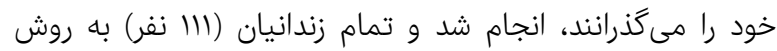
سرشمارى وارد مطالعه شدند. شعر اردبيل بهعنوان مركزيت ادارى-سياسى استان اردبيل در دشتى
مباحث، عوامل مذكور بيشتر توضيح داده مىشوند. تراكم و ازدحام،

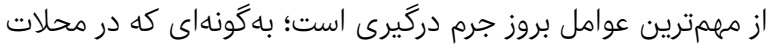

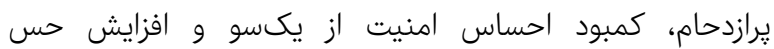

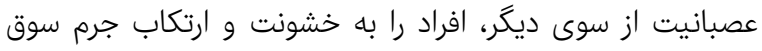

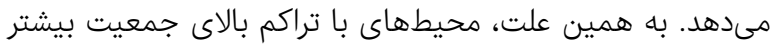

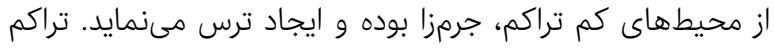

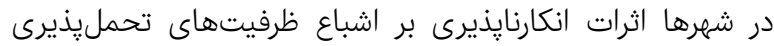

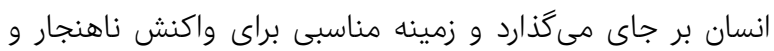
ارتكاب جرم به شمار مىرود. قدرت تحمليذيرى انسان در بسيارى

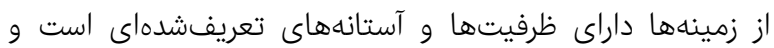

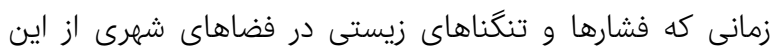

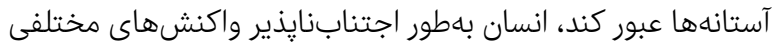

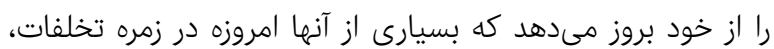

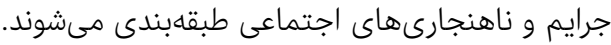

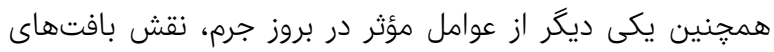

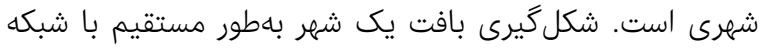

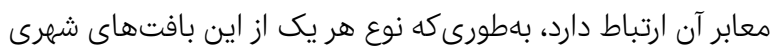

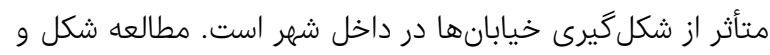

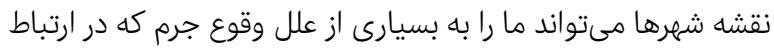

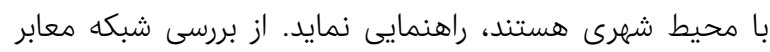

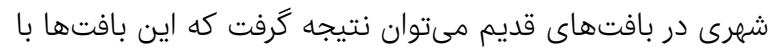

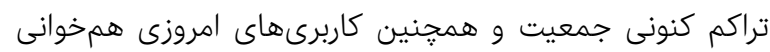

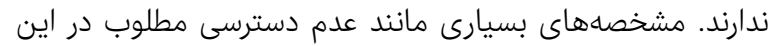

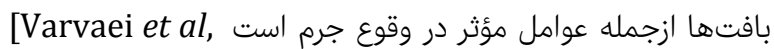

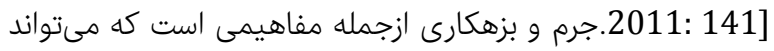

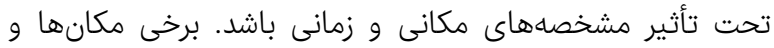

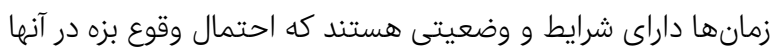

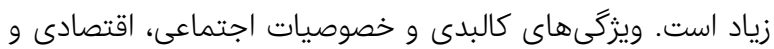

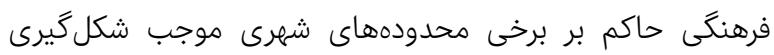

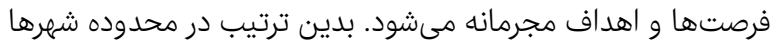
كانونهايى شكل مي كَيرد كه تعداد جرايم بسيار بالاترى در مر مقايسه

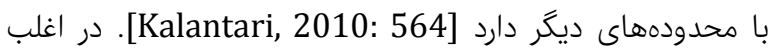

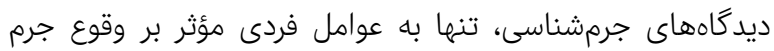

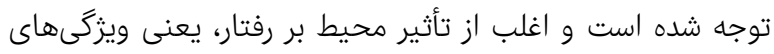

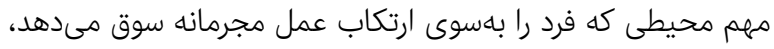

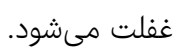

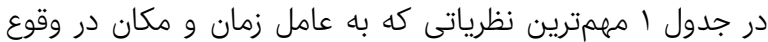

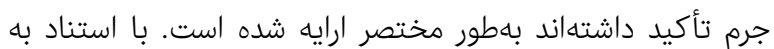

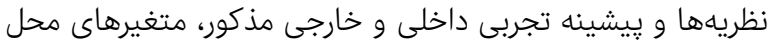

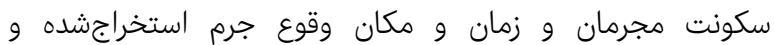

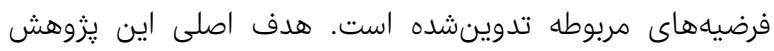

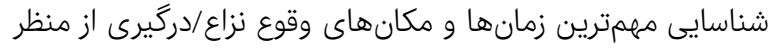
كنشَّران (زندانيان بر اثر دركيرى) شهر اردبيل بودان 


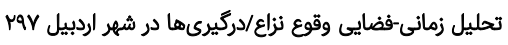

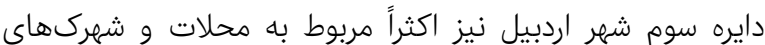

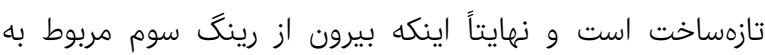
ييرامون شهر اردبيل است محلات اين محدوده اكثراً از روستاهاى

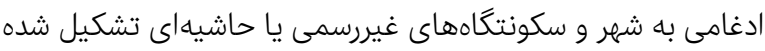

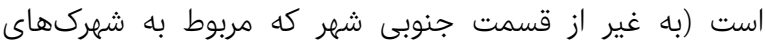

تازمساخت است) (شكل r r).

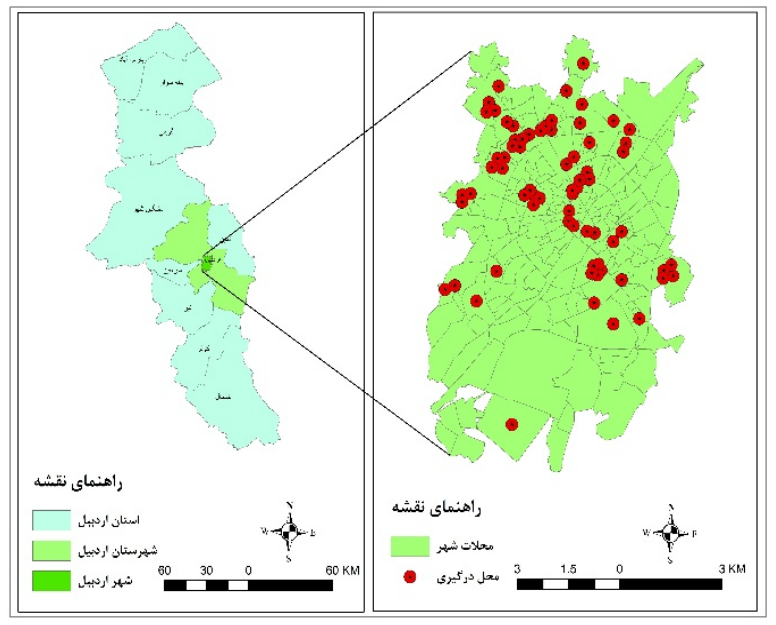

شكل () نقشه موقعيت شهر اردبيل در استان
به همين نام واقعشده و بهصورت شعاعى گسترشيافته است.

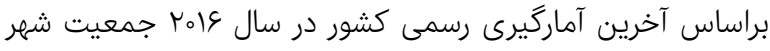

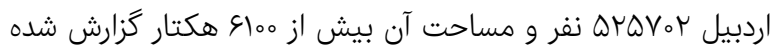

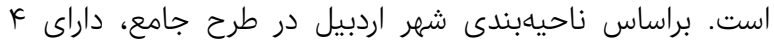

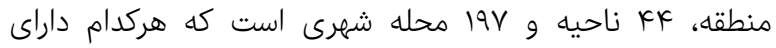

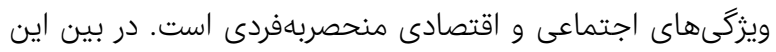
محلات شهرى، انواع بافتهاى شهرى ازجمله روستاى ادغامشده،

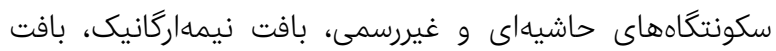

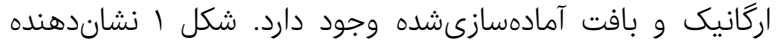

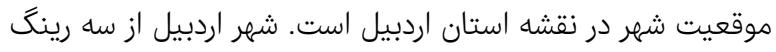

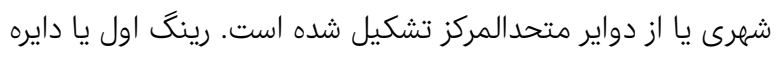

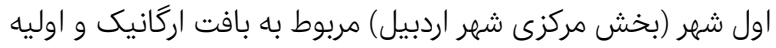

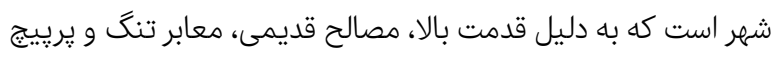

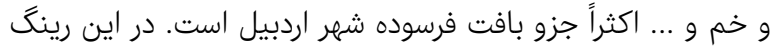

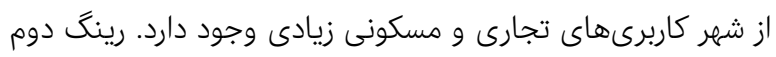

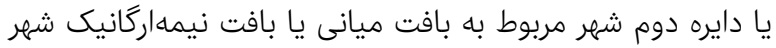

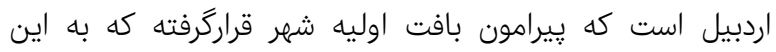

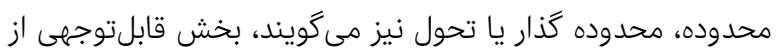

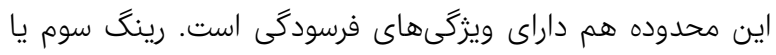

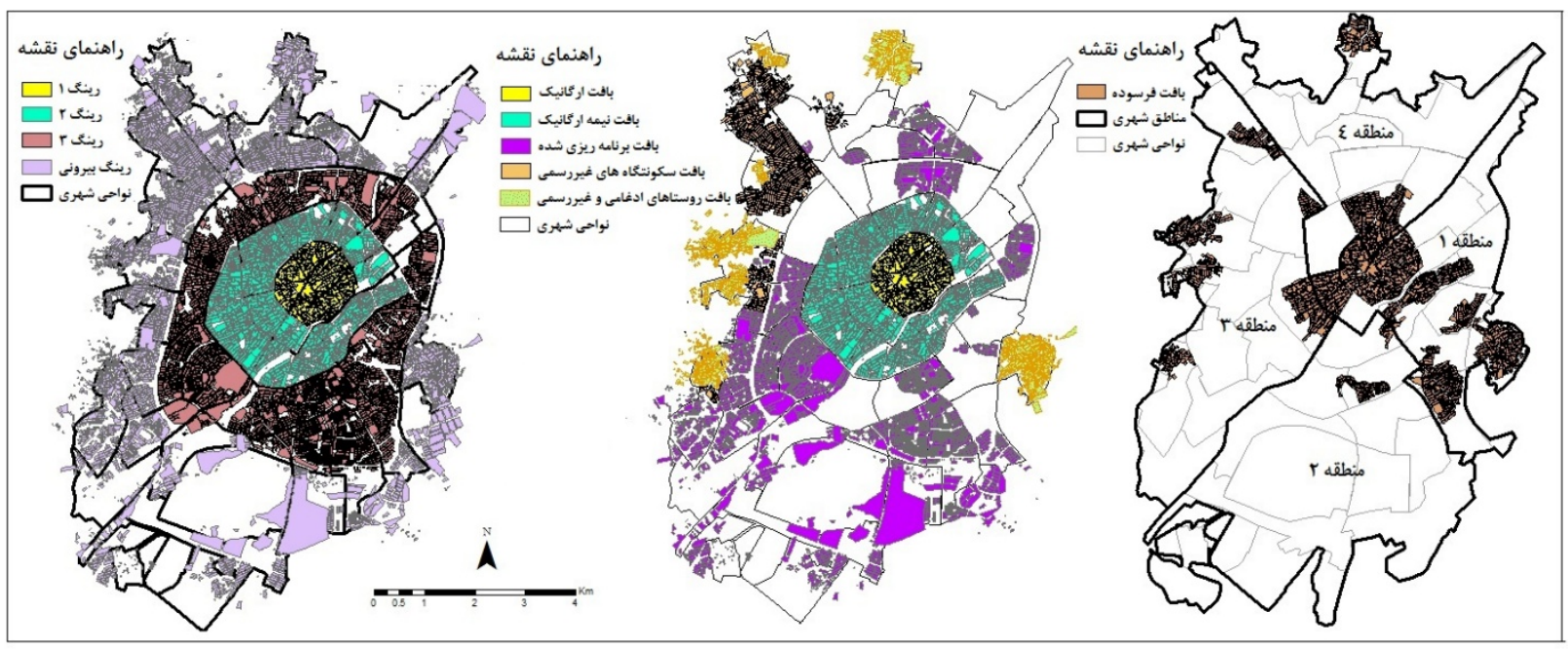

شكل r) نقشه مناطق شهرى، رينگ شهرى، نواحى شهرى و بافتهاى شهرى شهر اردبيل

بيش از •م \% مصالح اين مناطق از آجر و آهن، حدوداً 1 \% اسكلت

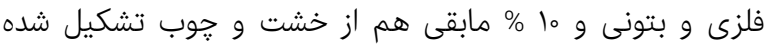

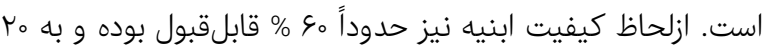
\% تخريب و r r \% ديگر هم مربوط به بناهاى نوساز است. تراكم

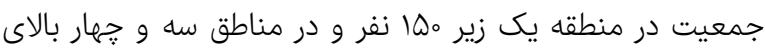

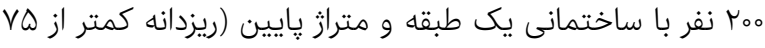

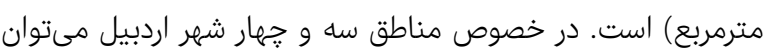

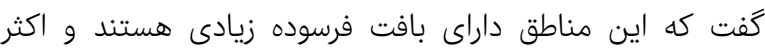

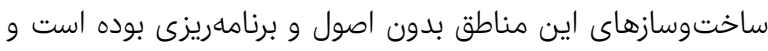
اينكه بيشتر روستاهاى الحاقى به شهر در اين دو منطقه است است. لازم

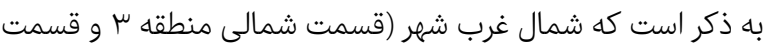

از نظر منطقهبندى شهرى هم اردبيل داراى \& منطقه شهرى است.

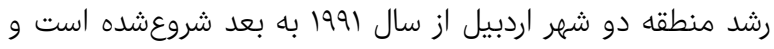
اين منطقه شهرى، منطقه با برنامهريزى ساختهشده شهر اردئ اردبيل

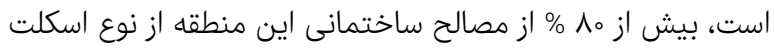

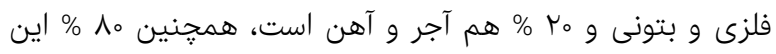

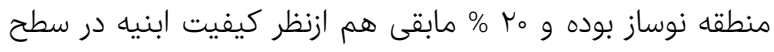

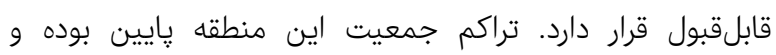

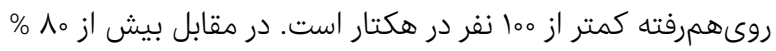

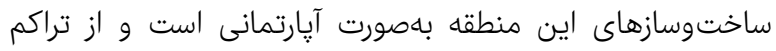

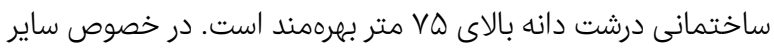

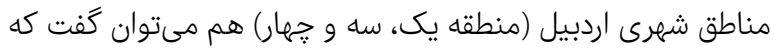


با توجه به جدول س مىتوان گفت كه بيشترين وقوع درگيرى در

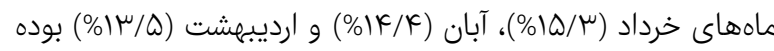

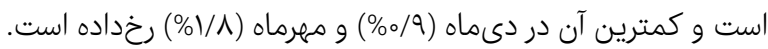

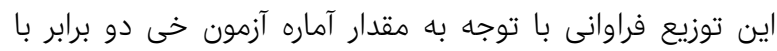

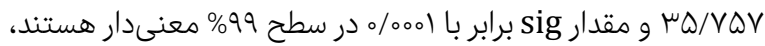

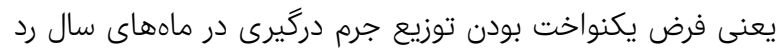

مى مود.

جدول س) بررسى توزيع ماه وقوع دركيرى بين زندانيان شهر اردبيل با استفاده از

\begin{tabular}{|c|c|c|c|c|c|}
\hline نتيجه & مورد انتظار & درصد & ماه وقوع درى & ماه وقوع & رديف \\
\hline$-0 / 7$ & N/7 & $V / T$ & فروردين & فروردين & 1 \\
\hline $7 / \varepsilon$ & $\wedge / 7$ & $1 \% / 0$ & ارديبهشت & ارديبهشت & $r$ \\
\hline$\Lambda / \varepsilon$ & $\Lambda / 7$ & $10 / \mu$ & خرداد & خرداد & $\mu$ \\
\hline$-\varepsilon / 7$ & N/7 & $\mu / 7$ & تير & تير & $\varepsilon$ \\
\hline$-1 / 7$ & N/7 & $T / \mu$ & مرداد & مرداد & 0 \\
\hline$r / \varepsilon$ & N/7 & $9 / 9$ & شهريور & شهريور & 7 \\
\hline$-7 / 7$ & N/7 & $1 / \wedge$ & مهر & مهر & v \\
\hline$V / \varepsilon$ & N/7 & $1 \varepsilon / \varepsilon$ & آبان & آبان & $\wedge$ \\
\hline$-1 / 7$ & $1 / 7$ & $7 / \mu$ & آذر & آذر & 9 \\
\hline$-V / 7$ & N/7 & $0 / 9$ & دى & دى & 10 \\
\hline$\circ / \varepsilon$ & $1 / 7$ & $1 / 1$ & بهمن & بهمن & 11 \\
\hline$-r / 7$ & $1 / 7$ & $0 / \varepsilon$ & اسفند & اسفند & ir \\
\hline- & - & 100 & & \\
\hline
\end{tabular}

نتايج جدول K نشان مىدهد كه بيشترين وقوع جرم در روزهاى

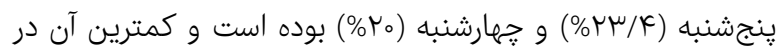

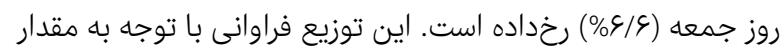

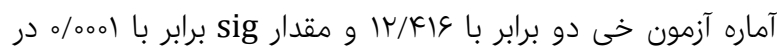
سطح 99\% معنىدار هستند، يعنى فرض يكنواخت بودن بابر توزيع

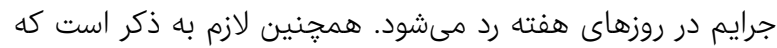

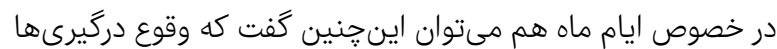
در نيمه سوم ماه بيشتر از نيمه دوم و بخصوص منيمون نيمه اول ماه

است.

جدول ع) بررسى توزيع روزهاى وقوع دركيرى بين زندانيان شهر اردبيل با استفاده

\begin{tabular}{|c|c|c|c|c|c|}
\hline نتيجه & فراوانى & درصد & فراوانى قابل & روزهاى وقوع & رديف \\
\hline$-1 / 1$ & $\Lambda / \Lambda$ & $11 / 7$ & v & روز شنبه & 1 \\
\hline$-0 / 9$ & $\Lambda / \Lambda$ & $\mid \pi / \varepsilon$ & $\wedge$ & روز يكشنبه & $r$ \\
\hline$-r / \Lambda$ & $\Lambda / \Lambda$ & 10 & 7 & روز دوشنبه & $\mu$ \\
\hline$\circ / r$ & $\Lambda / \Lambda$ & 10 & 9 & روز سهشنبه & $\varepsilon$ \\
\hline$\mu / r$ & $\Lambda / \Lambda$ & ro & Ir & روز جهارشنبه & 0 \\
\hline $0 / r$ & $\Lambda / \Lambda$ & $r \mu / \varepsilon$ & $1 \varepsilon$ & روز ينجشنبه & 7 \\
\hline$-\varepsilon / \wedge$ & $\Lambda / \Lambda$ & $7 / 7$ & $\varepsilon$ & روز جمعه & v \\
\hline - & - & 100 & 70 & مجموع & \\
\hline
\end{tabular}

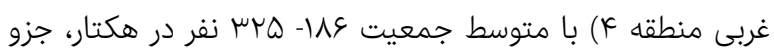
متراكمترين مناطق شهر محسوب مىشود. مصالح بهاركارفته در

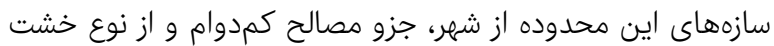

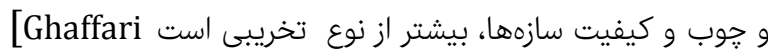
.et al, 2017:60]

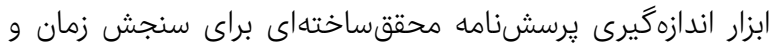
مكان درگيرى و شامل V سئوال بود (K سئوال در بخش زمان زمان

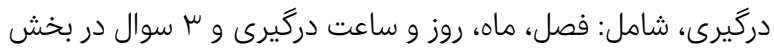

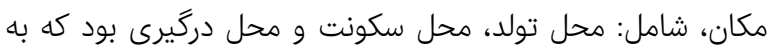

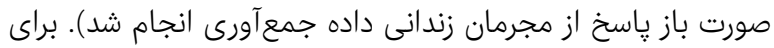

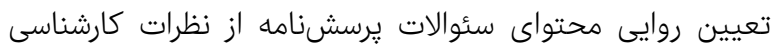

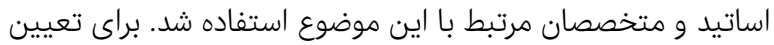

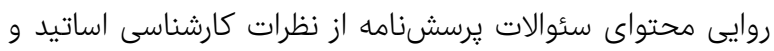

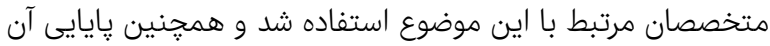

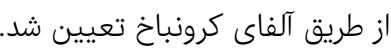
براى توصيف و تحليل دادهها، از آزمونهاى آمارى در قالب نرمافزئ ترار SPSS 19 شد. بامنظور انجام تحليلهاى زمان (فصل، ماه، روز و ساعت) وقوع درگيرى از آزمون خىدو و بهمنظور بررسى رابطه بين كانونهاى لهاى

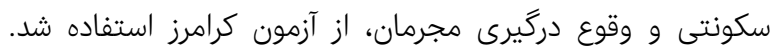

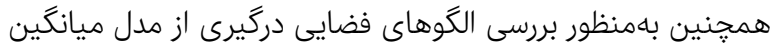

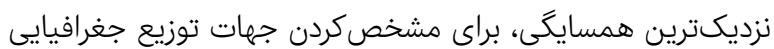

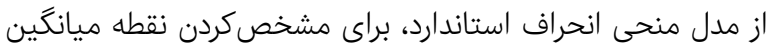

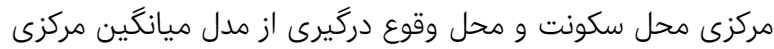

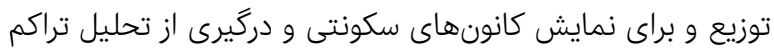
كرنل استفاده شد.

\section{يافتهها}

تحليل زمانى نزاع/درگيرى در شهر اردبيل

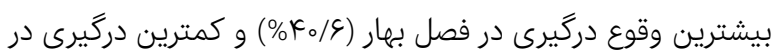

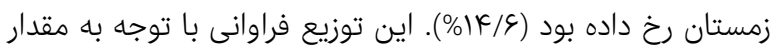

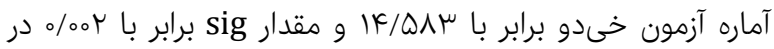

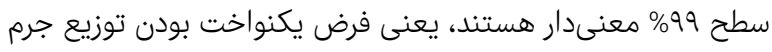
درگيرى در فصول سال مىشود (جدول r).

جدول r) بررسى توزيع فصل وقوع درگيرى بين زندانيان شهر اردبيل با استفاده از

\begin{tabular}{|c|c|c|c|c|c|}
\hline نتيجه & مورد انتظار & درصد & فراوانى قابل & فصل وقوع & رديف \\
\hline 10 & $r \varepsilon$ & $\varepsilon_{0} / 7$ & $\mu q$ & بهار & 1 \\
\hline-0 & $r \varepsilon$ & $19 / 1$ & 19 & تابستان & $r$ \\
\hline 。 & $r \varepsilon$ & ro & $r \varepsilon$ & پاييز & $\mu$ \\
\hline-10 & $r \varepsilon$ & $1 \varepsilon / 7$ & $1 \varepsilon$ & زمستان & $\varepsilon$ \\
\hline- & - & 100 & $9 \varepsilon$ & \multicolumn{2}{|c|}{ مجموع } \\
\hline
\end{tabular}




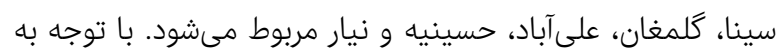

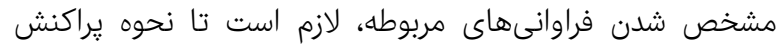
فضايى محل درگيرى و محل سكونت در سطح محلات و بافتهاى شهرى بر روى نقشه ارايه گردد.

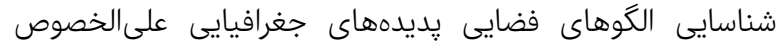

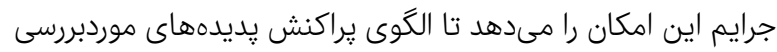

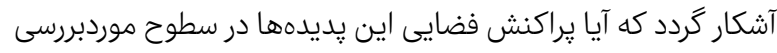

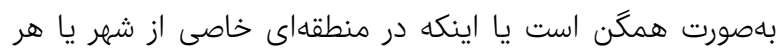

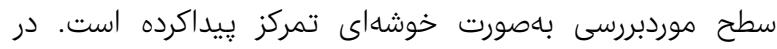

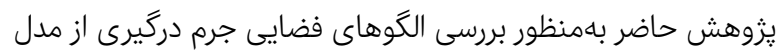

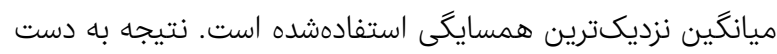

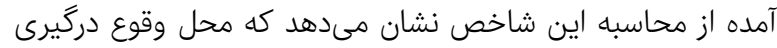

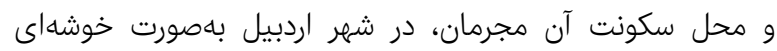

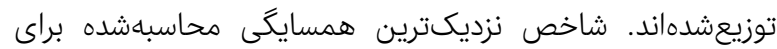

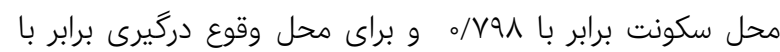

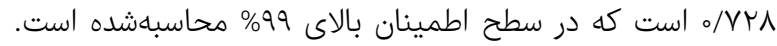

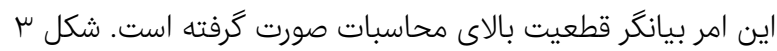

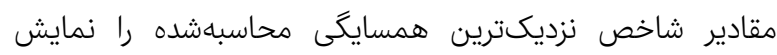
مىدهد. با توجه به الكَى خوشهاى يراكنش فضايى محل سكونت و محل

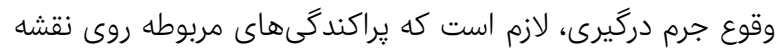

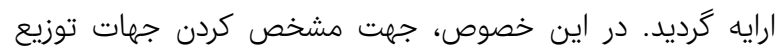

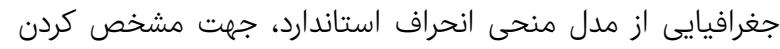

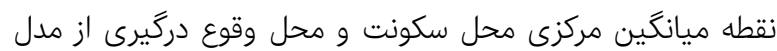

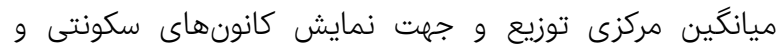

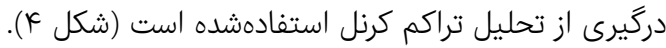

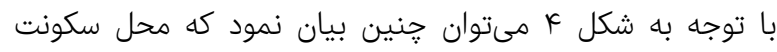
مجرمان جرم درگيرى در شهر اردبيل در جهت جغرافيائ دئ مركزى

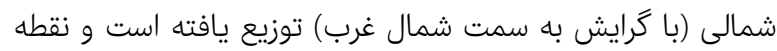
ميانكين مركزى محل سكونت همرمرز شهر و محله عباسيه است،

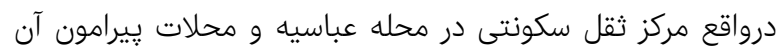

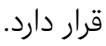

با توجه به جدول ه مىتوان گفت كه بيشترين وقوع جرم درگيرى

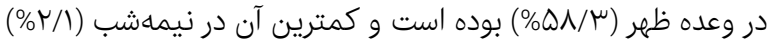

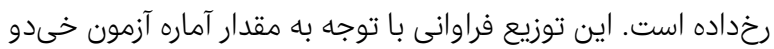

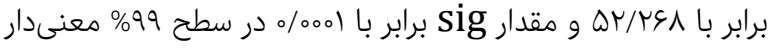

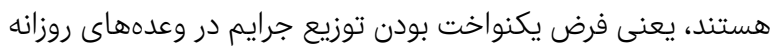

رد مىشود.

جدول 0) بررسى توزيع وعدههاى روزانه (ساعات) وقوع درگيرى زندانيان شهر اردبيل با استفاده از آزمون خىدو تروني

\begin{tabular}{|c|c|c|c|c|c|}
\hline نتيجه & فراوانى & درصد & فراوانى & وعدههاى روزانه وقوع & رديف \\
\hline$-N / 7$ & $9 / 7$ & $1 / 0$ & 1 & ساعت ا-0 (نيمه & 1 \\
\hline$-\varepsilon / 7$ & 9/7 & $10 / \varepsilon$ & 0 & ساعت 7-10 (صبح) & $r$ \\
\hline $1 N / \varepsilon$ & $9 / 7$ & $O \Lambda / \mu$ & r & ساعت 11-10 (ظهر) & $\mu$ \\
\hline$-r / 7$ & $9 / 7$ & $1 \varepsilon / 7$ & V & ساعت 17-19 (عصر) & $\varepsilon$ \\
\hline$-r / 7$ & $9 / 7$ & $1 \varepsilon / 7$ & v & ساعت r-ro- (شب) & 0 \\
\hline - & - & 100 & $\varepsilon \wedge$ & & \\
\hline
\end{tabular}

تحليل مكانى نزاع/درگيرى در شهر اردبيل

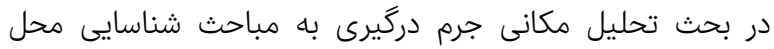

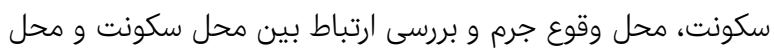

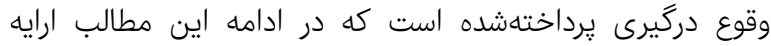
شدهاند. برابر با يافتههاى مستخرج از يرسشنامه، از تعداد ال'

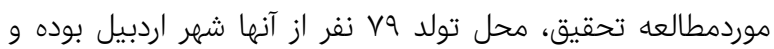

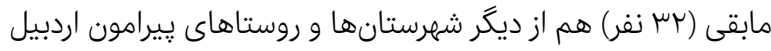

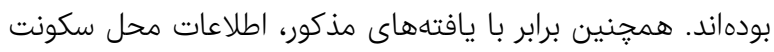

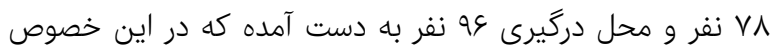
مىتوان جنين بيان نمود كه محل سكونت اكثر مجرمان زندانى به

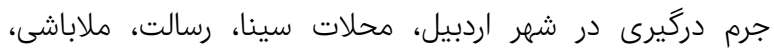

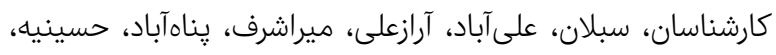

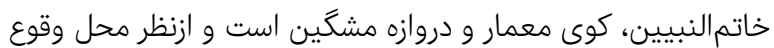

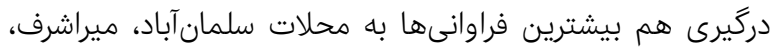

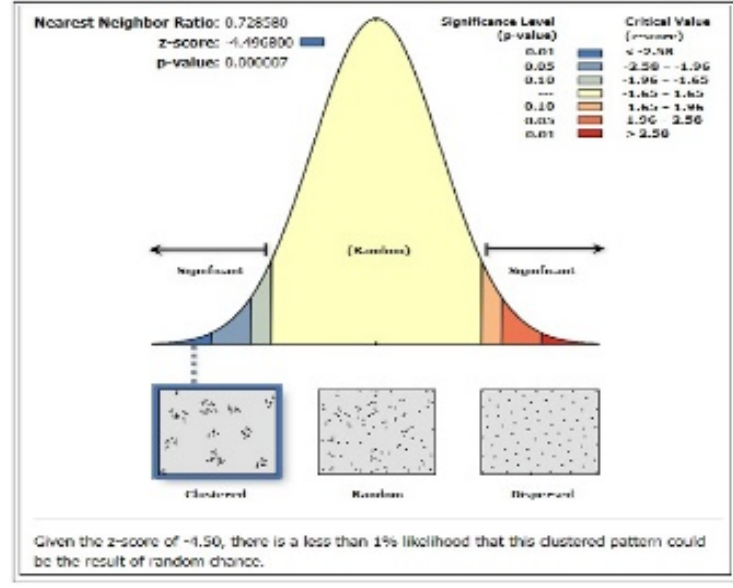

Geographical Researches Quarterly Journal

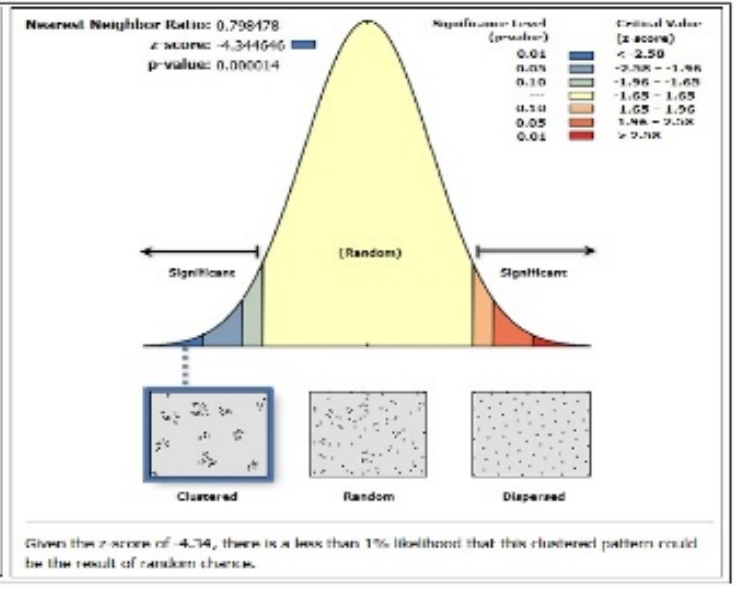

شكل سا) الكَى توزيع فضايى محل سكونت و محل وقوع درگيرى در شهر اردبيل 


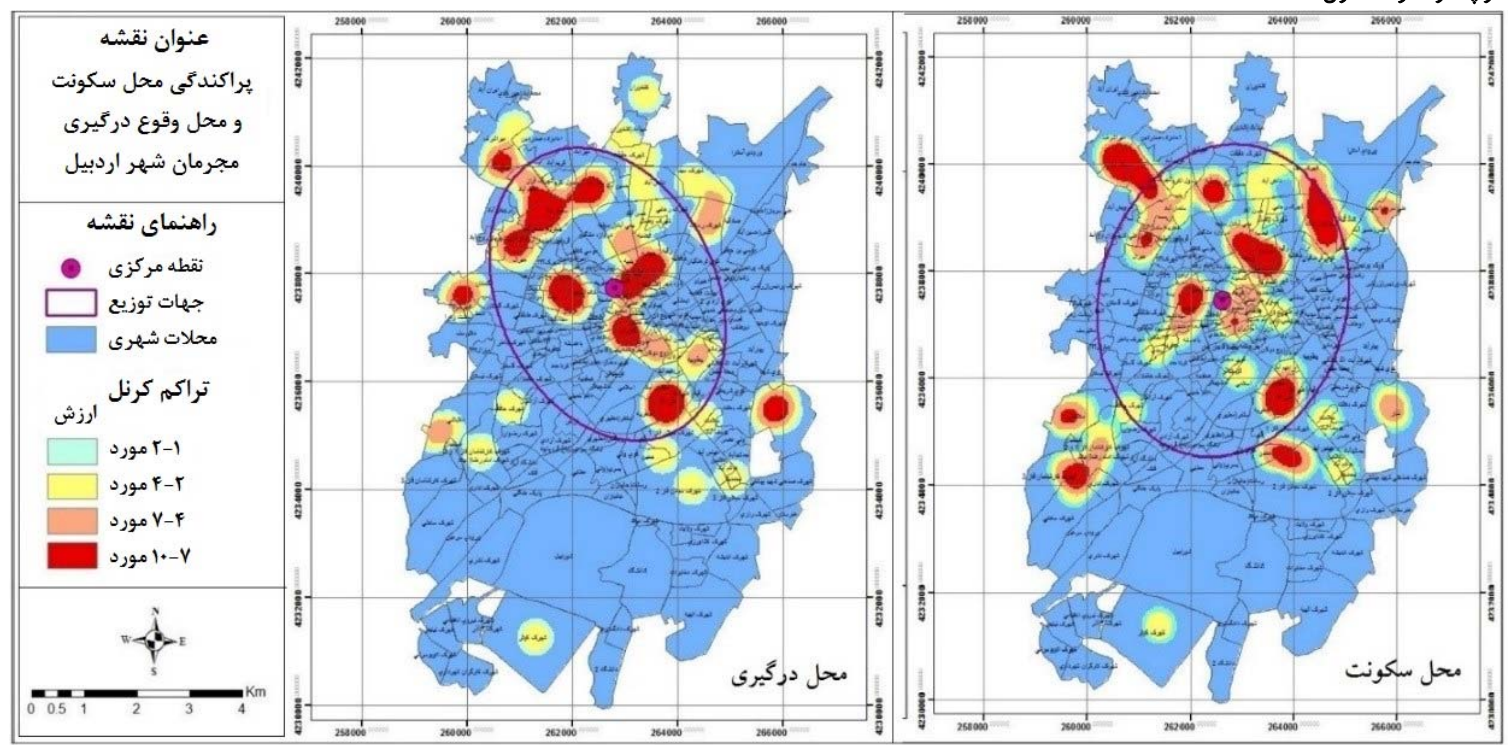

شكل ع) نقشه يراكندگى محل سكونت و درگيرى مجرمان زندانى به جرم درگيرى شهر اردبيل

از بين ها نفر از زندانيان شهر اردبيل هم كه محل جرمشان مربوط

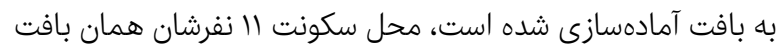

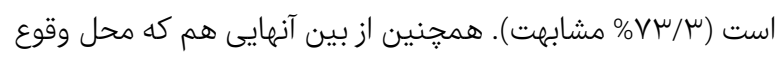

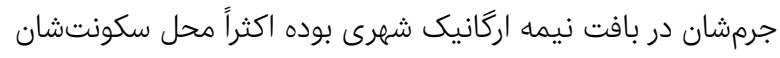

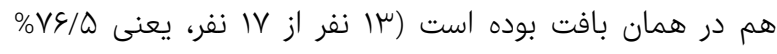

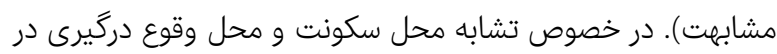

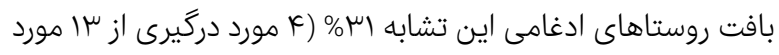

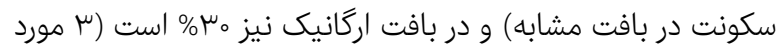

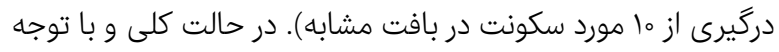

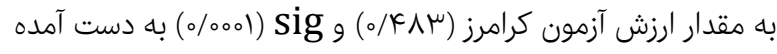
مىتوان گفت كه رابطه معنىدارى بين محل سكونت و محل وقوع إمراء جرم مجرمان وجود دارد.

جدول 7) بررسى رابطه بين محل سكونت و محل دركيرى مجرمان با استفاده از

\begin{tabular}{|c|c|c|c|c|c|c|}
\hline جمع & روستاى ادغامى & حاشيهاى & آمادهسازى & نيمهاركانيك & |رگانيك & محل سكونت و درگيرى \\
\hline 0 & - & 1 & - & 1 & $\mu$ & بافت ارگانيك \\
\hline rr & 1 & r & r & س & $\varepsilon$ & بافت نيمهارگانيك \\
\hline ro & 0 & 0 & 11 & r & r & بادافت شازهد \\
\hline 10 & $\mu$ & 9 & 1 & 1 & 1 & بافت حاشيهاى \\
\hline v & $\varepsilon$ & r & 1 & - & - & بافت روستاى \\
\hline $\mathrm{V} \varepsilon$ & $1 \pi$ & 19 & 10 & IV & 10 & جمع \\
\hline
\end{tabular}

با توجه به شكل ه مىتوان گفت كه محل سكونت و محل وقوع

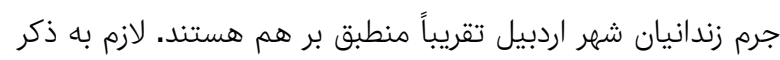

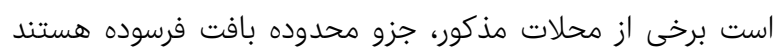

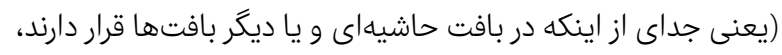

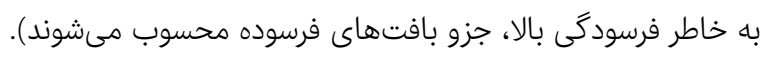

تحليل تراكم كرنل هم بيانكر اين امر است كه تراكم سكونتى در

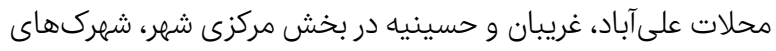

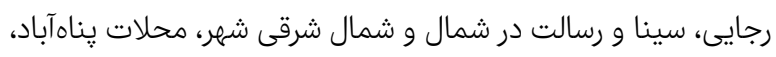

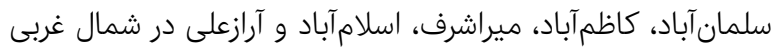

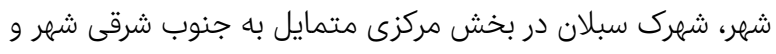

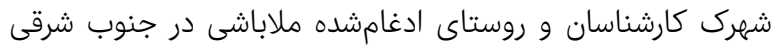
شهر، است، به اين مفهوم كه اين محلات كانونهاى اصلى سكونتى مجرمان جرم درگيرى شهر اردبيل هستند.

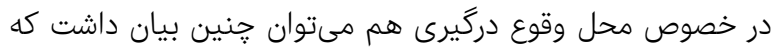
محل وقوع درگيرى مجرمان زندانى به جرم درگيرى در شهر درى اردير اردبيل

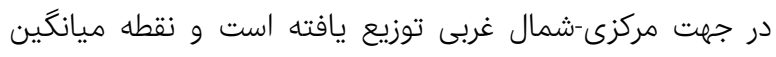
مركزى محل درگيرى در مركز شهر و محله قاسميه قرارگرفته است.

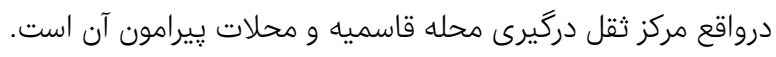

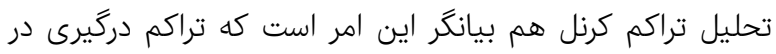

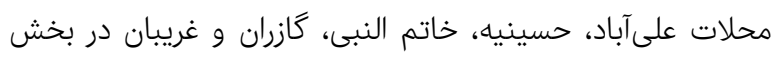

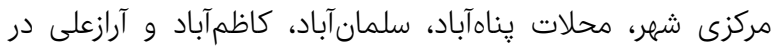

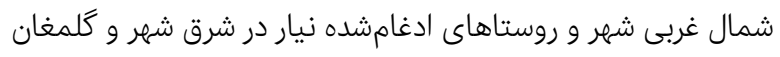
در غرب شهر، هستند. به اين مفهوم كه اين محلات كانونهاى روسئاي اصلى درگيرى در شهر اردبيل هستند.

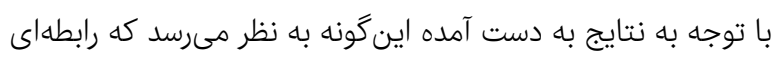
بين محل وقوع جرم با محل سكونت مجرمان وجود داشته باشد، از بـان

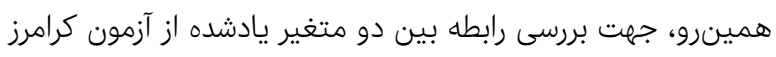

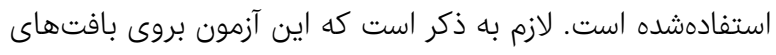

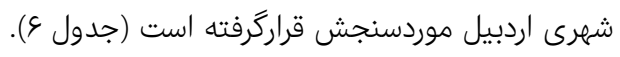

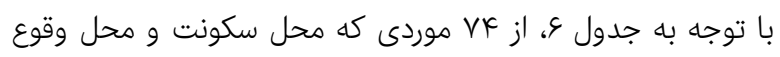
جرم آنها ذكرشده (داده جمعآورىشده)، محل جرم 19 نفر از آنها در مرد بافتهاى حاشيهاى شهر اردبيل بوده است كه ازاينبين 9 نفرشان إندان در همان بافت (بافت حاشيهاى) سكونت داشتهاند، يعنى حدوداً \%FV 
شهرى است. ازلحاظ بافت شهرى هم بيشترين محل سكونت مربوط

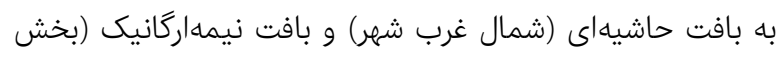

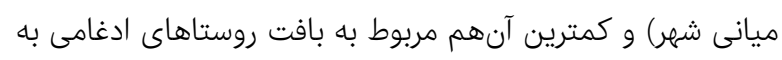

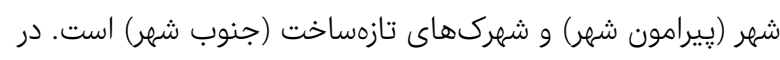

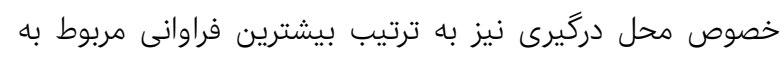

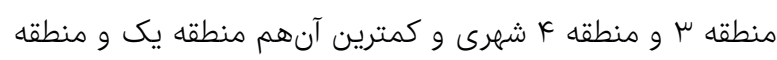

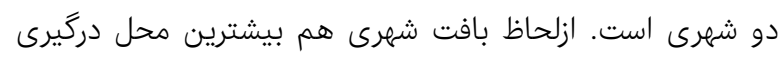

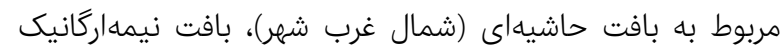

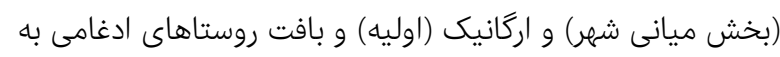

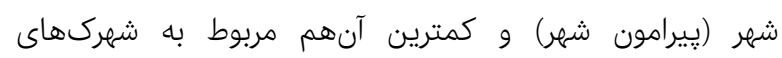
تازمساخت (بخصوص جنوب شهر) است.
از همينرو، لازم است وضعيت سكونت و وقوع درگيرى در اين

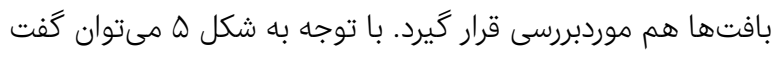

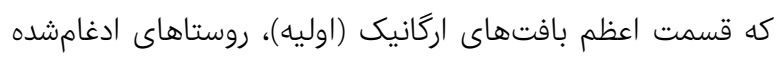

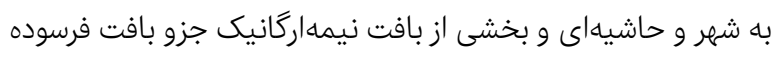

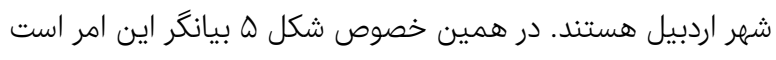

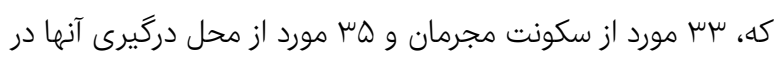

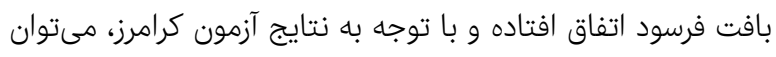

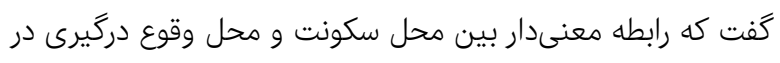

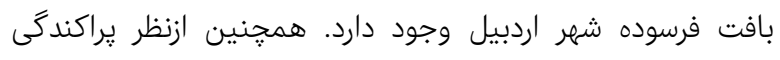

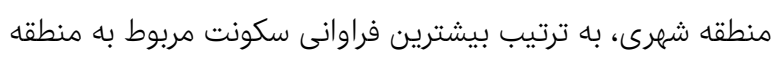
جهار و منطقه سه شهرى و كمترين آنهم منطقه ب و من منطقيه 1

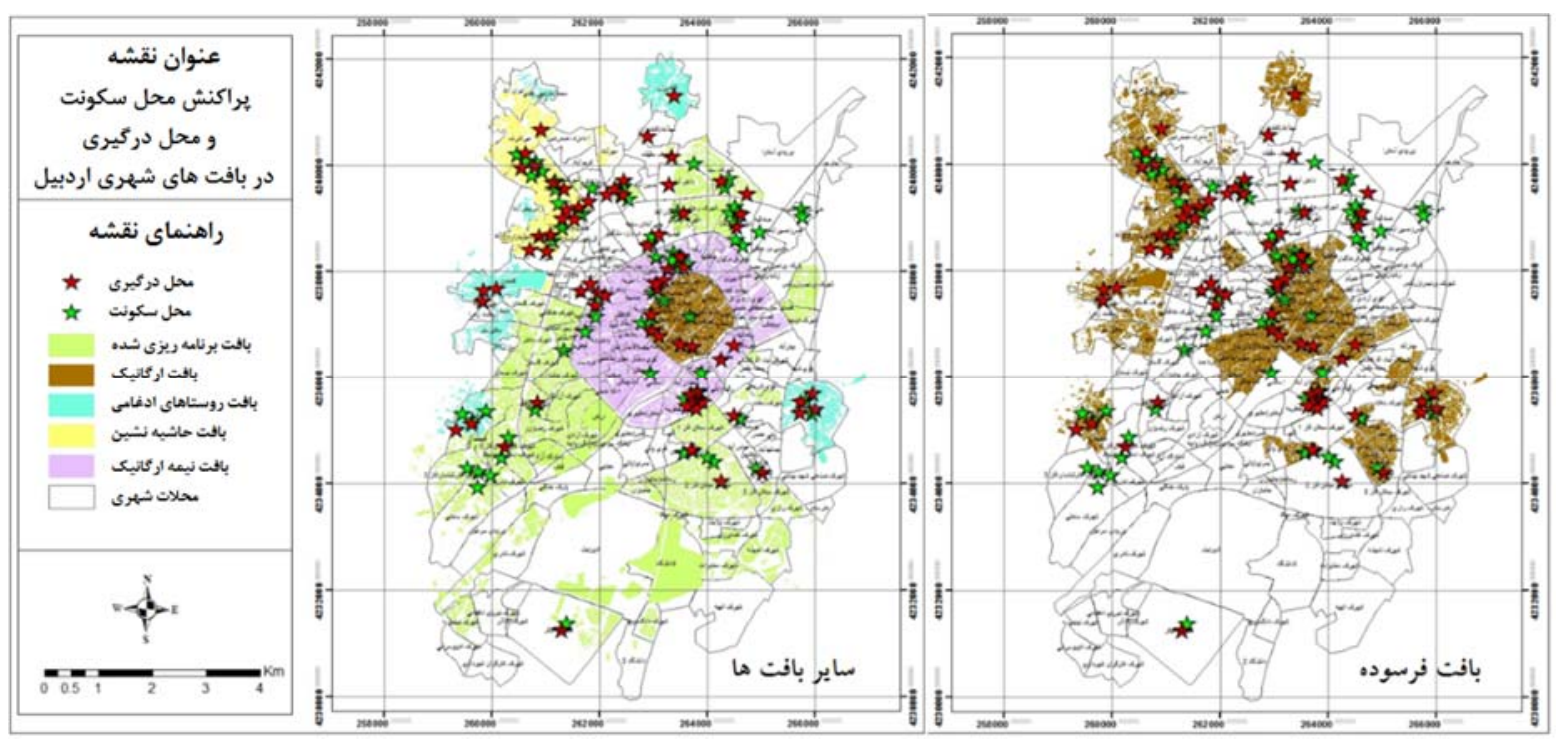

شكل ه) محل سكونت و محل وقوع دركيرى مجرمان در بافتهاى شهرى اردبيل

نيز مورد تأييد قرار مىگيرد. جراكه توزيع جغرافيايى درگيرىها نشان

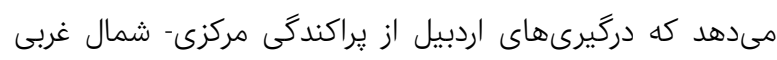

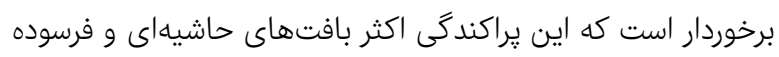

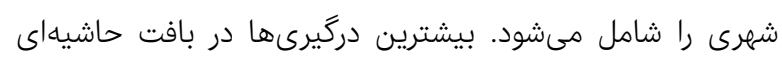

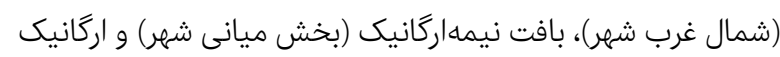

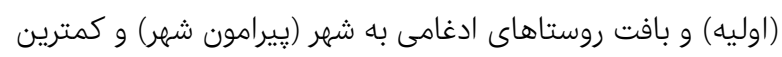

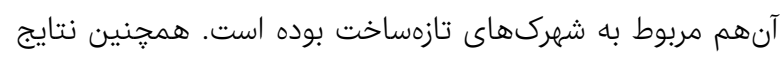

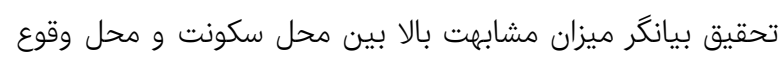

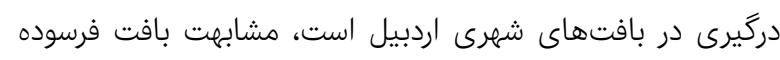

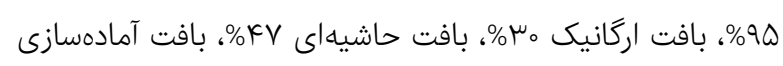

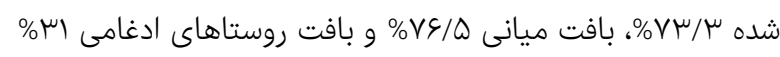
است، لذا مىتوان گفت كه محل سكونت و محل وقوع درگيرى ميانى منطبق بر هم هستند، در اين خصوص آزمون كرامرز ادعاى مطرحشده را در سطح معنىدارى هو\% تأييد مى هن هند. يعنى اينكه

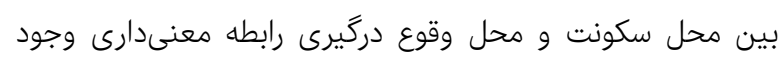

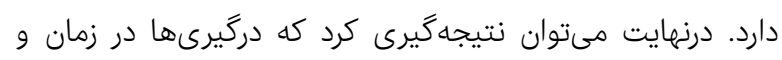

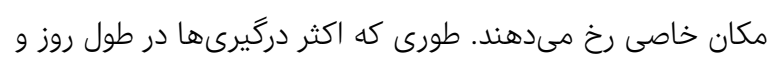

با توجه به نتايج بخش يافتههاى تحقيق، بم \% درگيرىها در فصل

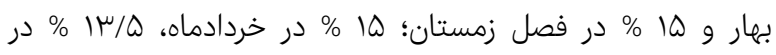

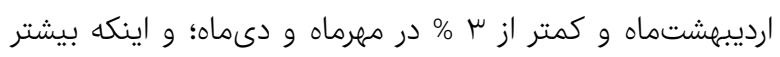

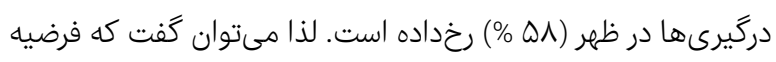

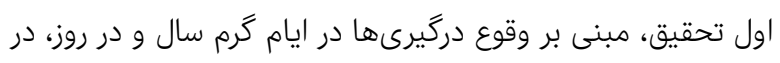

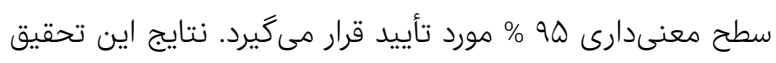

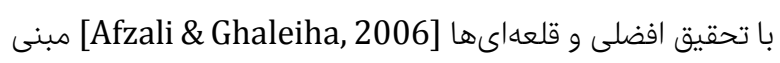
بر اينكه اكثر درگيرىها در عصر و در تابستان و مردادماه رخداده،

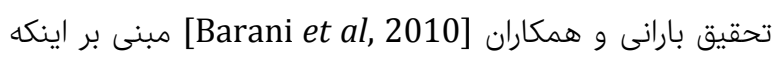
جرايم (عنف، شرارت و باجگيرى) در طول روز (بخصوص ظمر ونر و عصر)

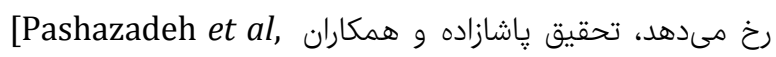

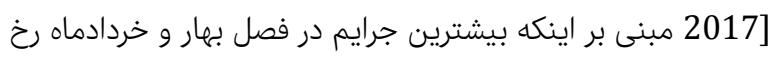

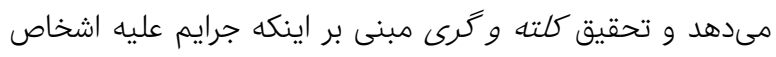
[Felson \& Clarke, بيشتر در گرما رخ مىدهد، همراستا است كاسنه .1998]

در خصوص مكان وقوع درگيرى هم مىتوان گفت كه فرضيه دوم 
منابع

Abdi T, Khalatbari A, Kamranisaleh B (2008). Effective factors on force robbery occurrence at Karaj city. Discipline Management Studies. 3(1):64-78. [Persian] Afzali S, Ghaleiha A (2006). Battery epidemiologic investigation and its damages for 1381 solar year referral persons for Hamedan law medical center. Law Medical Science. 12(2):73-78. [Persian]

Ahmadi S, Seyfoddini F, Kalantari M (2013). Guilty patterns spatial analysis at Tehran $17^{\text {th }}$ municipality region. Geography Sciences Applied Researches. 13(31):47-72. [Persian]

Barani-Birarvand M, Kalantari M, Jabbari K (2010). Guilty time-space patterns analysis at urban regions (case study: Robbery, force, depravity and levy at Tehran city central part). Social Discipline. 2(1):7-23. [Persian]

Felson M, Clarke RV (1998). Opportunity makes the thief practical theory for crime prevention. London: Police Research Series.

Foroozandeh S, Mirmorseli M, Akhavan-Mohseni M, Pour Esmali A, Ghadirzadeh A (2013). Investigation effective factors on battery toward among Ardebil citizens. Ardebil: Ardebil Province Head Justice Crime Occurrence Prevention and Social Assistant. [Persian]

Ghaffari A, Pashazadeh A, Aghaei V (2017). Measurement and priority of city resistance against earthquake (case study: Ardebil city and its quad part regions). Geography and Environmental Hazards. 6(21):45-65. [Persian]

Hossienzadeh AH, Navvah A, Anbari A (2011). Sociological investigation of effective factors on social battle toward, case study: Ahvaz city. Discipline Knowledge. 13(2):191-225. [Persian]

Kalantari M, Hedayati A, Abbasi E (2010). Investigation of field application amount and effect in crimes centers creation by using GIS (Geographical Information Systems) bases. Discipline Knowledge. 11(3):141-181. [Persian]

Kalantari M, Tavakkoli M (2007). Urban crime centers analysis and recognition. Crime Prevention Studies, Discipline Force Prevention Police Press. 2(2):75-100. [Persian]

Keynia M (1994). Criminology principals. 2nd Edition. Tehran: Tehran University Press. [Persian]

Modiri A (2007). Crime, violence and security feeling in city public spaces. Social Welfare. 6(22):11-28. [Persian]

Nouri J, Mohammad Hossieni R (2014). Ardebil province crime regions recognition. Ardebil: Head office of Ardebil province Jails.

Pashazadeh A, Zadvali F, Shirdel MB (2017). Recognition of crimes occurrence place and time at Ardebil city focused on delinquency and guilt theory. Ardebil Discipline Knowledge Special. (15):146-160. [Persian] Pour Afkari N (2011). Analysis of race tensions in Iran, selective articles of the first national congress about tribes and races role in prevention of social battles, Gachsaran. Tehran: Zeytoon-e Sabz Press. [Persian]

Shams M, Parhiz F, Mahdnejhad H, Ghamari M, Mohammadi K (2012). Analysis relationship between crime and population congestion in statistical blocks by using GIS (Geographical Information Systems) bases (case study: Zanjan-Islamabad informal residence place). Urban Planning and Research. (8):19-38. [Persian]

Varvaei A, Moghimi M, Ebadinejhad M, Moradi G (2011). Investigation effective factors of robberies close to suffering at Bandar-Abbas city (2010) by crime position prevention survey. Discipline Knowledge. 13(3)135-168. [Persian]
ايام گرم سال رخداده است. لذا مىتوان نتيجه گرفت كه شرايط

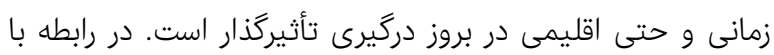

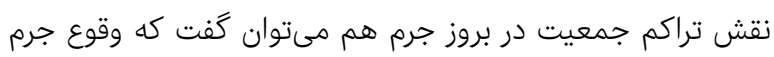

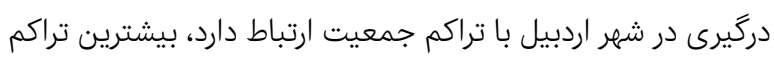
جمعيت شهر اردبيل به بخش مركزى و بخش شمال غربى مربوط است، جايى كه محل سكونت و محل وقوع اكثر درگيرىهاى شهر

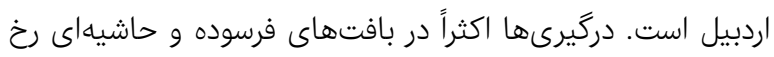

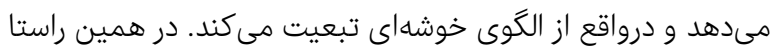
يافتههاى اين تحقيق با يافتههاى تحقيق كلانترى و ورو همكاران

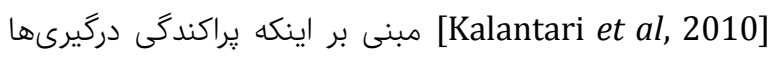

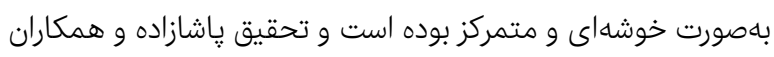

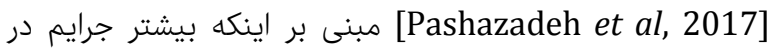

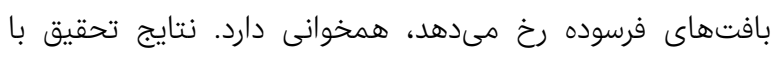

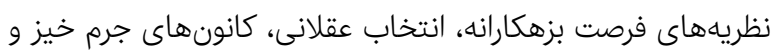

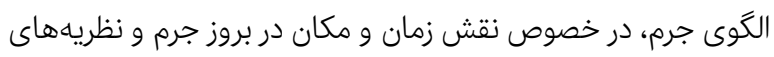

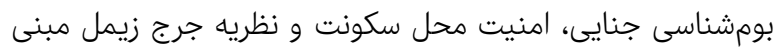
بر تأثير تراكم جمعيت و محل سكونت در بروز جرم، همسو بوده و

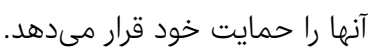

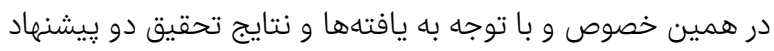
مناسب جهت كاهش جرم درگيرى ارايه مى گرددد. وقوع درگيرى اكثراً

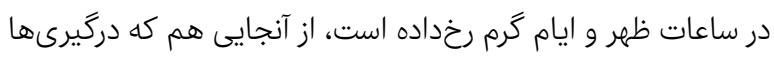

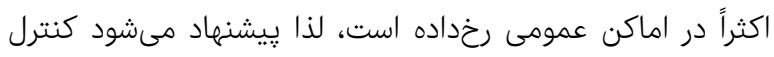

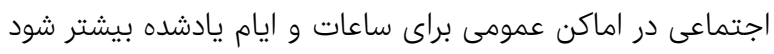

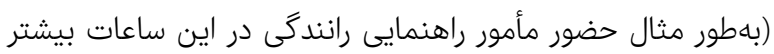

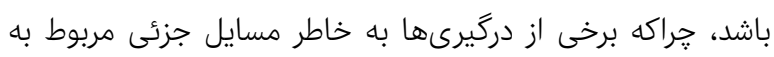

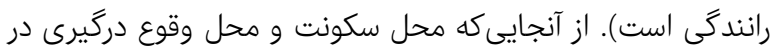
بافتهاى مركزى و حاشيهاى شهر اردبيل بوده است كه اين بافتها إنها

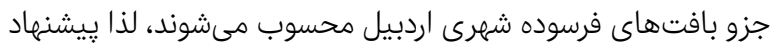

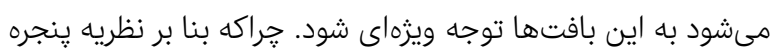
شكسته و بومشناسى جنايى، محيط زندگى بر بروز جرم تأثيرگذار

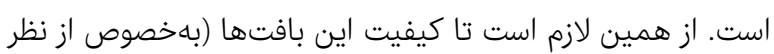
كالبدى (ابنيه، معابر و...)) بهبود يابد.

نتيجه

زمان و مكان از عوامل تأثيرگذار در بروز نزاع/درگيرى هستند، اما با توجه به شرايط زمانى و مكانى، اثرات متفاوتى دارند.

تشكر و قدردانى: موردى از سوى نويسندگًان گزارش نشده است.

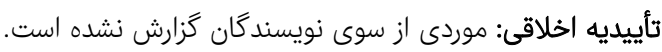

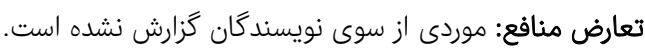

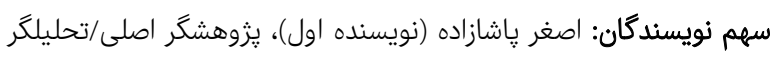

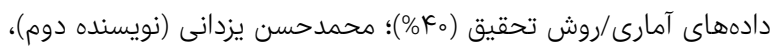

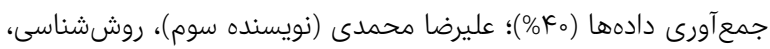

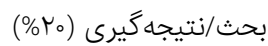
منابع مالى: موردى از سوى نويسندكان گزارش نشئده است. 